\begin{tabular}{|c|c|c|}
\hline \multicolumn{3}{|c|}{ TOTOBUANG } \\
\hline Volume 9 & Nomor 1, Juni 2021 & Halaman $1-13$ \\
\hline
\end{tabular}

\title{
KAJIAN LINGUISTIK KEBUDAYAAN DALAM TUTURAN RITUAL SÈF ALUMAMA MASYARAKAT BOTI DI NUSA TENGGARA TIMUR (Anthropolinguistic Study of Sèf Alumama Ritual Speech in Boti Community East Nusa Tenggara)
}

\author{
Iswanto \\ Institut Agama Kristen Negeri Kupang \\ Jl. Cak Doko, Oebobo, Kupang, Nusa Tenggara Timur \\ Pos-el: iswantoyohanes@ rocketmail.com
}

Diterima: 17 Juli 2020; Direvisi: 21 April 2021; Disetujui: 22 April 2021

doi: https://doi.org/10.26499/ttbng.v9i1.229

\begin{abstract}
Anthropolinguistics studies examines linguistic phenomena based on a linguistic scientific perspective and not cultural studies. The phenomenon of language is the phenomenon used $e$ in various events. This study examines Sef Alumama' ritual speech in the Boti community. The data in this study are recorded, transcribed, translated, and coded with the principle of managing corpus data. Specific theories and methods are used to answer the question of how is the study of anthropolinguistics applying in the ritual speech 'Sef Alumama' at the Boti community in East Nusa Tenggara? The main theory in this research is anthropolinguistics theory with cognitive semiotic theory as a specific theory. The results showed that a lexicon has linguistic attributes connected textually and intertextually. This lexicon or lingual form can be visualized in a cognitive map based on linguistic principles. Furthermore, Dawan's morphosyntaxis shows specific characteristics in the use of pronouns. In-depth studies conclude that the pronoun is used as a semantic interpretation and harmonization of oral literary sounds.
\end{abstract}

Keywords: Linguistik Kebudayaan, Boti, Semiotik Kognitif

Linguistik kebudayaan menjadi ranah pengkajian bahasa yang menelaah fenomena kebahasaan berdasarkan sudut pandang keilmuan linguistik dan bukan studi budaya. Fenomena kebahasaan adalah fenomena penggunaan bahasa dalam berbagai peristiwa. Penelitian ini mengkaji tuturan dalam ritual Sef Alumama pada masyarakat Boti. Data dalam penelitian ini ialah tuturan ritual yang direkam, ditranskripsi, ditranslasi, dan dikodekan dengan prinsip pengelolahan data korpus. Teori dan metode yang spesifik digunakan untuk menjawab pertanyaan bagaimana kajian linguistik kebudayaan dalam tuturan ritual 'Sef Alumama' pada masyarakat Boti di Nusa Tenggara Timur. Teori payung dalam penelitian ini ialah teori linguistik kebudayaan dengan teori semiotik kognitif sebagai teori spesifik. Hasil penelitian menunjukkan bahwa sebuah leksikon memiliki atribut kebahasaan yang dapat bergayut secara tekstual bahkan intertekstual. Leksikon atau bentuk lingual ini dapat divisualisasikan dalam peta kognitif berdasarkan prinsip kebahasaan. Lebih lanjut, morfosintaksis bahasa Dawan menunjukkan ciri spesifik dalam penggunaan pronomina. Kajian mendalam menyimpulkan bahwa pronomina tersebut digunakan sebagai pemaknaan secara semantis dan harmonisasi bunyi sastra lisan.

Kata-kata kunci: Linguistik Kebudayaan, Semiotik Kognitif, Masyarakat Boti

\section{PENDAHULUAN}

Kajian linguistik kebudayaan berpijak dari fenomena berbahasa sebagai data yang dikaji dengan teori bahasa untuk mendeskripsikan bahkan membentuk narasi ideologis (Sibarani, 2018 hlm. 1). Salah satu paradigma filosofi bahasa yang digunakan ialah realisme sebagaimana yang dideskripsikan oleh Plato. Lebih lanjut, bahasa yang bersifat konseptual dihasilkan dari pengalaman yang hierarki dan lamakelamaan membentuk sistem konseptual kognisi individu yang berkembang dalam 
masyarakat pengguna. Pada tataran ini, bahasa sebagai sarana pembentuk gagasan merekonstruksi persepsi individual dalam sebuah pemaknaan budaya, baik secara mikrokosmos maupun makrokosmos. Hakikat bahasa tersebut menjadi media untuk memahami dan menjelaskan realitas budaya dalam masyarakat (Delanty, 2006 hlm. 15).

Kajian linguistik kebudayaan memiliki dimensi keilmuan yang luas. Penelitian ini menggunakan paradigma ilmu bahasa yang terwujud dalam hubungan tanda yang bersistem, membentuk persepsi, direpresentasikan dalam konteks, dan pada tataran tertinggi sebagai gambaran ideologi kelompok masyarakat tersebut (Liang, 2015 hlm. 169) . Pada tataran ini bahasa sebagai ekspresi budaya menelaah makna pada tataran tanda dengan asumsi asosiatif ide yang saling bergayut satu dengan yang lain. Gayutan ini juga terjadi pada tataran hubungan sosial, nilai, dan norma budaya. Secara filosofi bahasa, hal ini terkait dengan paradigma kognitif-realis menurut pandangan Plato (Tomlinson, $2014 \mathrm{hlm}$. 165).

Bahasa sebagai sistem tanda tidak hanya dipakai sebagai alat komunikasi dan pengungkapan pikiran, tetapi juga digunakan untuk mengungkapkan kesemestaan dalam sistem penandaan (Sataloff et al., 206 C.E.). Pikiran manusia sebagai dunia ide dipengaruhi oleh lingkungan sosial dan budayanya. Kekhasan budaya dapat terlihat salah satunya melalui bahasa dalam peristiwa budaya. Tuturan ritual yang memiliki ciri yang berbeda dengan bahasa sehari-hari merupakan gabungan tanda yang tersistem dan kait-mengait membentuk suatu kesatuan pengungkapan ide mengenai entitas tertentu. Lebih lanjut, de Saussure (1993, hlm.155) berpendapat bahwa bahasa dalam tataran langue (bahasa sebagai sistem) bersenyawa dengan kehidupan masyarakat dalam wujud kode-kode, ritus suatu agama, dan tanda-tanda lainnya. Unsur-unsur ini tidak hanya bersifat konkret, tetapi juga bersifat abstrak, dalam batasan benda tersebut tidak terindrai manusia. Sehubungan dengan hal ini, kosmologi sebagai sebuah realitas dapat dilihat dalam perilaku individu ataupun kelompok sosial dalam memaknai alam semesta dan menetapkan norma-norma untuk hidup selaras dengannya (Snell et al., 2015 hlm. 166--167).

Penelitian linguistik kebudayaan
sering menjadi perdebatan secara epistimologi. Rasionalisasi atas pendekatan keilmuan bidang bahasa (linguistik) atau bidang budaya (kajian budaya) (Iswanto, 2018 hlm. 46). Argumen yang dipakai dalam penelitian ini ialah linguistik kebudayaan berdasarkan epistimologi data bahasa dengan pendekatan teori kebahasaan. Penelitian-penelitian terbaru menunjukkan bahwa lenguistik kebudayaan memiliki cakupan pembahasan yang cukup luas. Linguistik kebudayaan bisa dikaitkan dengan pendidikan bahasa berbasis budaya (Manugeren et al., 2017 hlm. 44). Penggunaan leksikon budaya dapat membantu dalam transfer pengetahuan yang lebih komprehensif. Sistem kognisi budaya juga dapat menjadi bangunan persepsi dalam kelompok masyarakat tersebut, yang dapat digunakan dalam pembelajaran. Konfigurasi kognisi sosial membangun komunikasi yang partisipasi dalam kelompok belajar tersebut. Beberapa prinsip sistem kognisi sosial akan digunakan dalam penelitian ini. Perbedaan yang ingin dikaji ialah penggunaan data. Berbeda dengan penelitian Manugeren (2014), penelitian ini akan menggunakan data tuturan ritual yang memiliki struktur semantik yang kompleks, struktur morfosintaksis dengan penggunaan klitika, dan fitur prosidik yang berasosiasi satu dengan yang lainnya (Alexandra \& Lu, 2004 hlm. 2 ; Udoye, 2019 hlm. 49).

Lebih lanjut, paradigma praktis dalam penelitian ini menggunakan data etnografis masyarakat Boti. Secara geografis, Desa Boti terletak di Kecamatan 
Kie, Kabupaten Timor Tengah Selatan (TTS), Provinsi Nusa Tenggara Timur (NTT). Luas wilayah Boti 17,69 $\mathrm{Km}^{2}$. Masyarakat Boti tergolong dalam yang masih memegang teguh kepercayaan asli dan tata budaya dalam siklus kehidupan. Kepercayaan asli masyarakat ini dikenal dengan Halaika yang secara religiusitas mengimani uis neno 'raja langit' sebagai penguasa tertinggi dan uis pah ma nifu 'raja bumi dan air' sebagai pemelihara. Sistem kerpercayaan ini secara perilaku terlihat dalam sistem sembilan hari pada masyarakat Boti yang masih dilaksanakan hingga saat ini. Sistem sembilan hari ini yaitu Neon Kaet (hari keramat), Neon Li'ana (hari anak), Neon Ai (hari api), Neon Onen (hari doa), Neon Masikat (hari bersaing), Neon Suli (hari perdamaian), Neon Pah (hari bumi), Neon Besi (hari besi/logam), dan Neno Snasat (hari perhentian). Pada Neon Pah atau hari bumi, semua masyarakat suku itu dilarang menebang pohon dan merusak lingkungan. Neon Li Ana atau hari anak, para orang tua dilarang memarahi dan memukul anak-anak. Pada Neon Suli atau hari perdamaian, warga tidak boleh sembarang bertutur kata, sehingga tidak terjadi salah paham dan pertengkaran. Jika terjadi pertengkaran, maka semuanya dapat diselesaikan secara adat tanpa sanksi atau denda. Pada Neno Snasat (hari perhentian) hari keramat, hari keberuntungan dari persaingan sehat, dan hari pemberhentian dari segala aktivitas, untuk sejenak berdoa (Iswanto, $2020 \mathrm{hlm}$ 87--88). Penelitian Iswanto (2020) secara ekplisit menyertakan data tuturan ritual Sef Alumama 'membuka alu mama', walaupun penelitian yang sudah dilakukan memberikan gambaran menyeluruh mengenai teks tuturan ritual masyarakat Boti. Berkaitan dengan hal tersebut, penelitian dengan judul Nilai-nilai kearifan lokal dalam tradisi lisan takanab: kajian Ekolonguistik memaparkan tentang salah satu tradisi dalam bentuk tidak nyata (tangible) berupa batu dan air, kain tenun motif, dan rumah adat; juga melalui kearifan lokal tidak berwujud nyata (intangible) berupa bidal, perumpamaan, petuah, dan syair. Penelitian ini menggunakan teori etnolinguistik dengan pendekatan etnografi komunikasi (Nesi et al., $2010 \mathrm{hlm} .71$ )

Objek penelitian ialah tuturan ritual Sef Alumama 'membuka alu mama'. Ritual ini menggunakan bahasa Dawan atau juga dikenal dengan bahasa Uab Meto. Karakteristik bahasa Dawan yang digunakan juga khas, yaitu bahasa sastra tinggi yang tidak mudah diterjemahkan. Ritual ini dilakukan tiga tahun setelah kematian seorang laki-laki dalam suku Boti. Selama masa itu alu mama (sejenis tas dari kain adat yang berisi barang-barang pribadi) disimpan dalam ume kbubu 'rumah bulat'. Karakteristik kebahasaan yang khas dan budaya asli inilah yang akan dibahas lebih lanjut dalam tulisan ini.

Sebagaimana dijelaskan di atas, tujuan penelitian ini tidak hanya mengumpulkan data etnografis secara holistik, tetapi menganalisis dan mendeskripsikan data tuturan ritual sèf alumama 'membuka alumama' pada masyarakat Boti di Nusa Tenggara Timur dengan pendekatan antropolinguistik. Kajian antropolinguistik dalam penelitian ini secara khusus menggunakan teori semiotik de Sassure yang dikembangkan dengan prinsip semiotik kognitif (Zlatev, 2012 hlm. 2--3). Hasil dan pembahasan akan menjawab pertanyaan penelitian bagaimana kajian linguistik kebudayaan dalam tuturan ritual sèf alumama 'membuka tas' pada masyarakat Boti di Nusa Tenggara Timur? Penelitian ini secara spesifik akan membedah teks tuturan ritual sèf alumama 'membuka tas' ke dalam kelas kata dan dipetakan dalam peta kognitif. Dari proses ini, akan diperoleh kajian linguistik yang khas seperti jalinan ide konsep utama dan interpretasi teks. Oleh sebab itu, peneliti menggunakan teori semiotik kognitif sebagai pisau bedah dan diharapkan dapat 
memberikan kebaharuan dalam kajian antropolonguistik.

\section{LANDASAN TEORI}

Paradigma kebudayaan dan linguistik sebagai ilmu, mulai diperkenalkan dalam penelitian Sir William Jones pada akhir abad ke-18 mengenai bahasa Sansekerta dan Jacob Grimes pada awal abad ke-19 mengenai cerita rakyat dan regulasi pergesaran bunyi konsonan pada bahasabahasa Indo-Eropa. Penelitian Grimes menghasilkan temuan hukum Grimes yang menjadi salah satu dasar linguistik struktural abad ke-20 yang dipelopori oleh Ferdinand de Saussure (Casas \& Campoy, 1995 hlm. 207; Nosowicz \& Szerszunowicz, 2015 hlm. $125)$.

Pembahasan mengenai linguistik kebudayaan sebagai payung teori memberikan ruang kepada teori semiotik khususnya semiotik kognitif sebagaimana yang akan digunakan dalam penelitian ini. Dalam artikel ilmiah dengan judul Cognitive Semiotics: An Emergering Field for the Transdicilinary Study of Meaning menjelaskan tiga tingkatan analisis teks atau leksikon sebagai tanda. Ketiga tingkatan tersebut dijelaskan dalam tiga karakter analisis tanda. Karakterisitik pertama ialah triangulasi yaitu metode pencarian makna subjektif, intersubjektif, dan objektif. Interpretasi makna pada tingkatan subjektif (first-person) berupa analisis konseptual, dan intuisi sistematis dari penutur asli. Produk dari tingkatan ini dapat berupa persepsi, penggambaran mental, dan analisis kebahasaan (fonologi, morfologi, dsb). Selanjutnya, interpretasi makna intersubjektif (second-person) dilaksanakan dengan bentuk yang lebih imajinatif dan menghasilkan analisis interaksi sosial. Interpretasi makna objektif (third-person) dilaksanakan dengan jaringan tanda, peta alur pikir (tanda dimaknai melalui hubungan dengan tanda lainnya tanpa melibatkan analisis interpreter yang berlebihan) (Zlatev,
2009 hlm 3-4, 2012 hlm. 2-3). Karakteristik ini digunanakan pada perilaku tertutup pada individu atau kelompok masyarakat tertentu. Triangulasi metode memungkinkan analisis data pada tataran semiotik yang lebih dalam, menyeluruh, memiliki tingkat keobjektifan yang tinggi. Hal tersebut digambarkan sebagai berikut.

\section{Bagan 1}

Skema Triangulasi Metode Semiotik Kognitif (diadaptasi dari Zlatev, 2012 hlm.15)

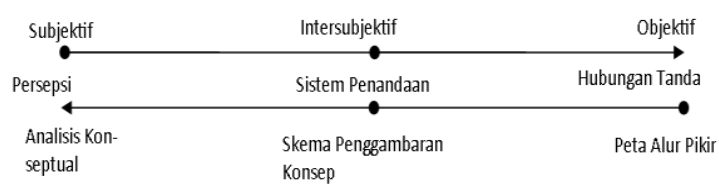

Karakteristik kedua, penggunaan fenomenologi sebagai metode penelitian. Penggunaan metode ini, memungkinkan penggunaan hermeneutik sebagai metode analisis data, sehingga, hasil yang diperoleh dapat menyentuh esensi pemaknaan tanda yang mendalam. Karakteristik ketiga, kedinamisan yaitu (1) melihat interpretasi tanda dalam berbagai tingkatan, (2) bersinergi dengan berbagai bentuk dalam interpretasi budaya (dalam penelitian ini mengacu kepada dimensi sosiokultural dan ideologi), (3) mengutamakan kedinamisan proses (interpretasi) dibandingkan dengan produk (interpretasi) statis dan (4) memahami hubungan esensi makna melalui interpretasi proses pengelolahan tanda secara alami. Penjelasan lebih lanjut berkaitan dengan transdisiplin ilmu yang luas sebagai penopang teori. Disiplin ilmu tersebut mencakup (1) semiotik (tidak hanya pada satu aliran pemikiran tetapi dapat berupa kombinasi, (2) linguistik (pendekatan melihat makna sebagai esensi bahasa), (3) antropologi, (4) kognitif, dan (5) filsasat (Durst-Andersen, 2008 hlm. 2-4 ).

Teori semiotik kognitif pada penelitian ini mengacu pada prinsip semiotik de Saussure dengan beberapa penggabungan 
konsep lainnya. Prinsip-prinsip kognitif dalam semiotik de Saussure digunakan untuk mencari relasi tanda, mencari relasi referen (sistem penanda), membentuk bangunan persepsi terhadap suatu entitas (Kemple, 2019 hlm. 59). Penggunaan semiotik dikotomi de Saussure diperkaya dengan pandangan semiotik Moris untuk membedah data linguistik kebudayaan. Pada tataran sintagmatik dan paradigmatik konsep bahasa sebagai alat berpikir dan berkomunikasi harus dibentuk dari interaksi tanda. Interaksi tanda dapat dimaknai sebagai kombinasi antara konsep dan gambaran akustik (Bragg et al., 2019 hlm. 21-22). Dengan kata lain, tanda terbentuk dari kesatuan antara dua aspek yang tidak terpisahkan satu sama lain, yaitu signifiant (penanda) dan signifie (petanda). Signifiant adalah aspek formal atau bunyi pada tanda itu, sedangkan signifie adalah aspek kemaknaan atau konseptual. Tanda pada tataran langue bersifat konkret sebagai hasil kerja sama antara penanda dan petanda (Durst-Andersen et al., 2013).

Lebih lanjut, sebuah teks terdiri atas sebuah topik global yang mengendalikan keseluruhan teks. Prinsip ini dapat diterapkan untuk membangun hubungan antartanda dalam teks tuturan ritual. Peta alur pikir de Beaugrande dapat dilihat seperti di bawah ini.

A great black and yellow $V-2$ rockett 46 feed long stood in a New Mexico desert. Empty, it weighed five tons. For fuel it carried eigh tons of alcohol and oxigen.

Everything was ready. Scientists and generals withdrew to some distance and crouhed behind earth mounds. Two red flares rose as a signal to fire the rocket.

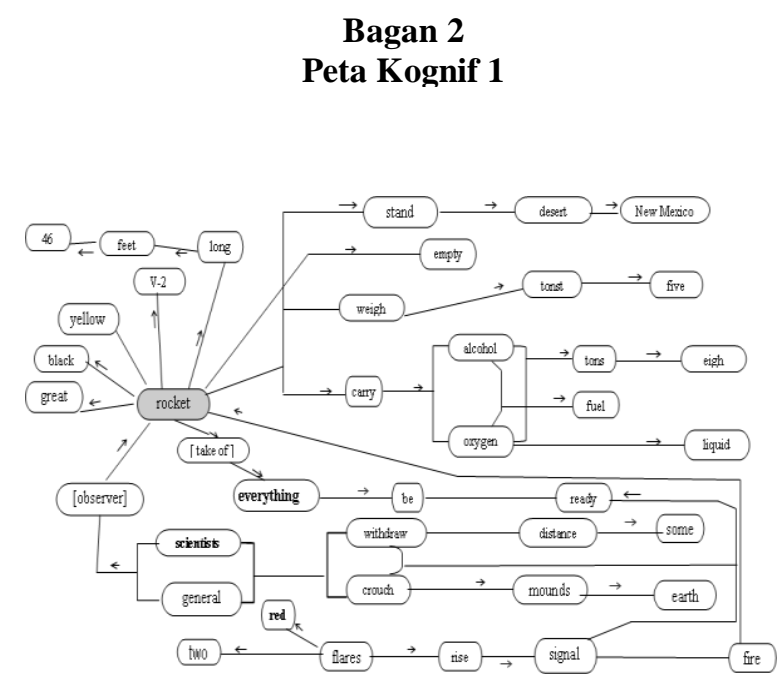

Peta Kognif 1

Menggambarkan alur pikir dalam sebuah wacana. Bentuk lingual 'rocket' menjadi topik global yang bergayut dengan fitur-fitur yang terdapat dalam teks tersebut.

(diadaptasi dari Beaugrande, 1980:98)

\section{METODE}

Penelitian ini menggunakan paradigma penelitian kualitatif dengan dasar filosofis fenomenologi (Sundler et al., 2019 hlm. 12). Penelitian fenomenologi berangkat dari sebuah fenomena. Pada tataran linguistik kebudayaan terlihat dalam penggunaan leksikon tertentu untuk menunjukkan ide dan membangun struktur ideologi (Ellis, 2019 hlm. 25). Fenomenologi mempertanyakan bukan apa yang tampak tetapi makna di balik yang tampak tersebut. Hierarkis dunia ide, secara abstraksi terlihat dalam petanda dan sistem penandaan untuk kemudian menjadi tanda kekhasan metode analisis teks seperti ini yang hanya dimiliki oleh kajian linguistik kebudayaan. Selain itu metode yang digunakan juga diperkaya oleh pendekatan hermeneutik untuk menganalisa teks pada tataran persepsi ideologi (Umanailo, 2019 hlm. 1-2).

Data primer dalam penelitian ini berupa data tuturan ritual yang diambil secara langsung pada saat ritual dilaksanakan. Narasumber ialah tua adat 
yang bisa menuturkan dan memiliki kategori sebagai pemangku adat 'meo' panglima. Identitas narasumber utama bernama Bota Benu, umur 80-an tahun, menguasai bahasa sastra dawan secara fasih. Narasumber pendukung berjumlah dua orang yaitu Namah Benu sebagai raja Boti dan juga Paulus Pobas sebagai interpreter budaya masyarakat Dawan (Santosa, 2016 hlm. 7071).

Metode wawancara mendalam digunakan untuk mengumpulkan data lain di luar tuturan ritual. Selain itu metode observasi juga digunakan untuk data etnografi. Penelitian ini dilaksanakan pada tahun 2019, dan menjadi rangkaian penelitian masyarakat Boti secara holistik yang dilaksanakan pada tahun 2010-2020. Jangka waktu penelitian yang panjang disebabkan karakteristik masyarakat yang tergolong dalam subjek penelitian data sensitif (Gehman et al., 2018 hlm. 284).

Pengelolaan data menggunakan metode pengelolaan data linguistik berbasis korpus. Data tuturan berupa verbatim di transkripsi menjadi data tulis, analisis menggunakan speech analyzer untuk menentukan matra dan bait. Selanjutnya data ditranslasi dengan teknik glosing tiga lapis untuk selanjutnya diberikan kode (TRKM) berdasarkan teknik korpus data penelitian bahasa (Jun, 2019). Transkripsi data penelitian linguistik memiliki kekhasan yaitu sistem penjelasan kata per kata dengan menggunakan kode kelas kata. Pada Penelitian ini beberapa singkatan yang digunakan di antaranya PREP (preposisi), KONJ (konjungsi), J (jamak), T (tunggal), RED (reduplikasi). Interpretasi data selanjutnya akan ditriangulasi dengan menggunakan metode triangulasi data etnografis. Teknik triangulasi ini akan dilaksanakan dengan cara mewawancarai kembali narasumber utama dan observasi kembali untuk memastikan kebenaran analisis data yang telah dilakukan. (Heath et al., 2020 hlm. 158)

\section{PEMBAHASAN}

Tuturan ritual Sèf Alu Mama 'buka Alu Mama' tergolong dalam tuturan ritual kematian (TRKM) yang diritualkan tiga tahun setelah kematian seseorang. Tuturan ritual kematian pada masyarakat Boti terdiri atas tuturan ratapan kematian, membuka $A l u$ Mama, dan tuturan ritual memberi makan arwah. Tuturan ritual kematian menandakan keberadaan manusia di tengah-tengah alam semesta. Tuturan ritual ini disampaikan sesaat setelah seseorang meninggal dunia sebagai ekspresi ratapan, yang bersifat sakral sehingga penuturannya dilakukan oleh pemimpin halaika. Tuturan ini disertai sahutan dari kelompok penutur atutas yang mengucapkan ulang kata terakhir.

Bahasa yang digunakan bahasa kesastraan dengan puisi yang khas, sehingga banyak struktur yang seakan-akan menyimpang dari kaidah-kaidah gramatikal bahasa Uab Meto pada umumnya. Matra I merupakan matra pembuka yang tidak disahut oleh atutas, gaya tuturnya sebagaimana seseorang mengucapkan judul atau tema tuturan. Untuk menyingkap makna figuratif perlu kiranya ditelusuri dan dicermati kata per kata dengan penerjemahan harfiahnya.

Alu Mama adalah tas yang biasanya terbuat dari kain tenun ikat. Tiap-tiap orang khususnya lelaki dewasa yang sudah berumah tangga memiliki tas ini untuk menyimpan barang-barang berharga. Dengan ukuran yang tidak terlalu besar, tentu saja barang yang disimpan yang nilainya tinggi, misalnya uang logam, emas dan perak. Di samping itu sebagai ciri khas masyarakat Boti, dalam tas Alu Mama itu tersimpan alat bersirih pinang (pisau kecil, cupak untuk menumbuh sirih pinang yang terbuat dari tanduk sapi. Ketika pemiliknya meninggal dunia tas Alu Mama yang diberlakukan sebagai barang keramat ini dibuka oleh semua anak perempuan dan laki-laki. Oleh karena diberlakukan sebagai barang keramat, yang memimpin membuka 
adalah pemimpin halaika. Dalam membuka dan membagikan isi Alu Mama itu diawali dengan tuturan rirual seperti yang terlihat berikut ini.

\section{Transkripsi}

\section{Sèf Alumama (TRKM 2)}

\section{Alki ana féto moné olif tataf}

Tabu $i$ hi ama alu i tabun tia

Hé ta 'sana' in nésan néu alaki

Mésé'-mésé' mès naténaf mak anlomi

mak anbéti

Sa' lèk bi tas i inanan

Mès in naiti anfani in maus

Naiti anfani in balé' nakko' in amaf

Henfani mnaut néu mésé'-mésé' bi tabu

amnémat

Kalu himi mnau hi ama bi hinékan

Maiti balé i fani taka' néu ki mésé-mésé'

\section{Terjemahan}

\section{BUKA ALU MAMA}

Semua anak perempuan, laki-laki, adik dan kakak

Tiba saatnya, lihatlah tas bapakmu

Untuk dibuka dan isinya dibagikan

Perhatikan dan pilihlah isinya

Apa yang ada di dalam

Apa yang kamu pilihkan jadi pusaka

Ambilah kepunyaan bapakmu

Jadikanlah peringatan di waktu yang

akan datang

Jadikanlah kenangan di hatimu

Jadikan sebagai tanda hai kamu semua

Tuturan Sef Alumama 'buka tas Alu Mama' berbentuk puisi lisan dengan penggalan larik-larik yang pendek-pendek didominasi suara berat vokal a yang berkombinasi dengan konsonan nasal mendominasi tuturan. Keharmonisan orkestra di sana-sini tersisipi suara ringan vokal [i] dan [é]. Nuansa tutur ini mendukung sikap keseriusan mereka dalam membuka benda yang diberlakukan sebagai peninggalan yang memiliki nilai keramat.

Untuk mencermati kebermaknaan tuturan tersebut perlu kiranya diterjemahkan secara harfiah seperti yang ditampilkan berikut.

Séf alu mama
buka alu mama
'Membuka

Alki ana féto moné Semua anak perempuan lakilaki

olif tataf (TRKM 2.1)

adik kakak

'Semua anak perempuan, laki-laki, adik dan kakak

Tabu $i$ hi ama alu Saat ini kamu bapak tas

i tabun tia (TRKM 2.2)

ini waktu tiba

'Kini sudah tiba saatnya, melihat tas bapakmu'

Hé ta'sana' in nésan

PREP 1J-buka 3T isi-

néu ala ki (TRKM 2.3)

3T PREP semua 2J

'untuk kita buka semua isinya'

Mésé-mésé' mès naténaf satu-satu nanti berpikir

makanlomi mak anbéti (TRKM 2.4)

KONJ mau KONJ pilih 'perhatikan satu per satu, mana yang kau ingini dan kau pilih'

Sa' lèk bi tas $i$ nanan apa yang di tas ini dalam 'apa yang ada di dalam tas ini' (TRKM 2.5) 
Mès in naiti anfani in maus PREP 3T ambil menjadi 3T pusaka

'Ambillah untuk menjadi pusaka' (TRKM 2.6)

Naiti anfani in bale' nakko' Ambil menjadi 3T barang 3T-

in amaf (TRKM 2.7)

PREP 3T bapak

'Ambilah kepunyaan bapakmu'

Henfani mnaut néu mésé-mésé'
KONJ ingat PREP RED-satu

bi tabu amnemat (TRKM 2.8)

di waktu akan datang

'Jadikanlah peringatan di waktu yang akan datang'

$\begin{array}{lll}\text { Kalu } & \text { himi } & \text { mnau } \\ \text { KONJ } & \text { 2J } & \text { 2J-ingat }\end{array}$

hi ama bi hi nekan

2J bapak PREP 2J hati

'Jadikanlah kenangan di hatimu' (TRKM

2.9)

$\begin{array}{lll}\text { Maiti } & \text { balé } i & \text { fani } \\ \text { Ambil } & \text { barang ini } & \text { sebagai }\end{array}$

taka'néu ki mèsé-mèsé'

tanda untuk kamu satu-satu

'Jadikan sebagai tanda hai kamu

semua' (TRKM 2.10)

Dua matra puisi Séf Alu Mama 'membuka Alu Mama' merupakan bentuk perintah. Sebagaimana disebutkan di muka perintah ini disampaikan oleh halaika 'pemimpin agama suku Boti' atas nama keluarga. Yang menarik dalam tuturan ini adalah penyebutan urutan orang yang akan menerima isi Alu Mama, yaitu dimulai dengan ana féto 'anak perempuan', padahal dalam konteks komunikasi lainnya selalu mengedepankan laki-laki. Hal ini terimplisit persepsi kosmologi masyarakat Boti bahwa 8 perempuan Boti memikul tanggung jawab dan hak dalam mengurus harta kekayaan termasuk penghasilan.

Jika dilihat oleh orang umum, wujud tas Alu Mama tersebut tidak seberapa nilainya. Tas yang terbuat dari kain tenun Boti tentu sudah kumal karena sudah puluhan tahun. Dalam acara penting tas tersebut selalu dibawa, sehingga anak cucunya memperlakukannya dan menyikapinya bukan hanya sesuatu yang berharga, tetapi juga benda keramat. Berkaitan dengan hal tersebut, istilah maus 'pusaka' adalah nomina yang diberikan atribut pronomina 3T in 'dia'. Struktur bahasa puitika Dawan atau Uab meto sangat kaya klitika. Proses ini juga dikenal dengan metatesis. Penjelasan lebih lanjut dapat dilihat pada data TRKM 2.6-2.7, sebagaimana di bawah ini.

Mès in naiti anfani in maus
PREP3T ambil menjadi 3T
pusaka
'Ambillah untuk menjadi pusaka' (TRKM
2.6)
Naiti anfani in bale' nakko'
Ambil menjadi 3T barang 3T-
in amaf (TRKM 2.7)
PREP 3T bapak
'Ambilah kepunyaan bapakmu'

Berdasarkan data TRKM 2.6-2.7, larik Mès in naiti anfani in maus 'Ambillah untuk menjadi pusaka', terdapat pronomina in 'dia' yang melekat pada bentuk lingual Mès demikian juga anfani. Karakteristik seperti ini disebut sebagai metatesis oleh Hein Steinhauer. Pendapat lainnya menyatakan bahwa fungsi kelas kata 
pronomina tersebut sebagai klitik yaitu proklitik dan enklitik.

Rasionalisasi keterkaitan mikro dan makro linguistik ini dapat dijelaskan dengan pernyataan bahwa kehadiran bentuk proklitik dan enklitik tersebut berfungsi sebagai harmonisasi bunyi suku kata sebelum dan sesudah. Perlu diperhatikan bahwa tuturan ritual termasuk dalam bentuk puitika tinggi yang menyampaikan pesan religiusitas. Dengan demikian, konsep linguistik kebudayaan dalam fungsi komunukasi noninsani, dapat terlihat dalam data penelitian ini.

Untuk menyingkap makna tuturan Séf Alu Mama 'membuka alu mama' perlu kiranya alu pikir yang membangun tuturan tersebut yang dapat digambarkan dalam peta kognitif 2. Setelah dipetakan ada beberapa unsur yang tidak tergambar terutama pronomina persona II jamak hi him 'kalian' karena kata ini bereferensi kepada anak-anak yang akan menerima isi Alu Mama yang dalam tuturan dinyatakan oleh kelompok kata alki ana feto ana moné olif tataf 'semua anak perempuan anak laki-laki kakak beradik', juga pronomina III jamak in yang mengantikan isi Alu Mama yang dalam tuturan dinyatakan kelompok kata in nésan néu alaki 'semua isinya'. Pronomina in dalam rangkai kata di sini merujuk kepada $h i$ Alu Mama pada larik sebelumnya. Dalam peta juga terjadi penghilangan kelompok kata Sa'lèk bi tas $i$ nanan 'ápa yang ada di dalam tas ini' pengganti isi Alu Mama hi alu ama nésan néu alaki 'semua isi tas ayah kalian'.
Bagan 3

Peta Kognif 2

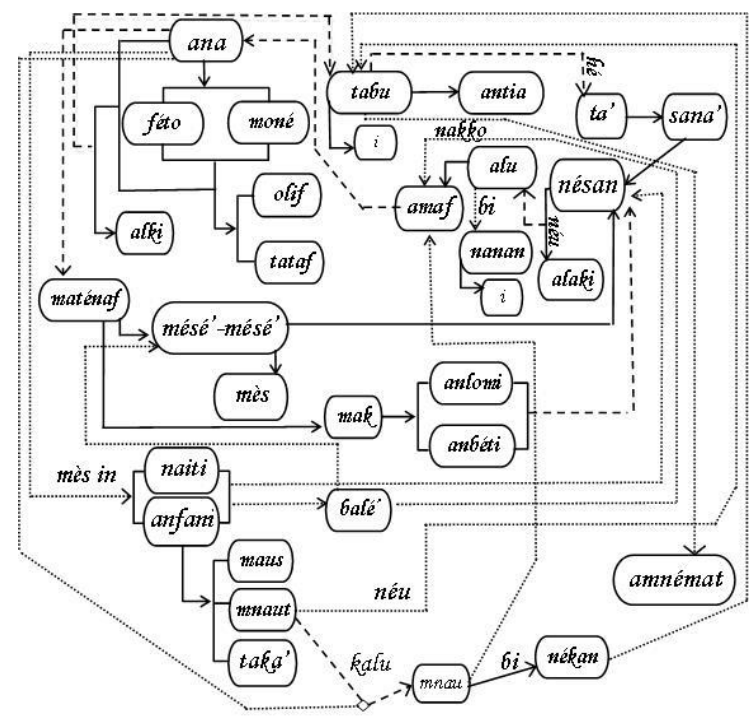

Peta Kognif 2. Alur Pikir Gayutan Antarkata dan Jalinan Antarlarik Antarmatra Tuturan Ritual Sef Alumama (garis putus-putus menunjukkan hubungan paradigmatik. Sedangkan garis tak putusputus menunjukkan hubungan sintagmatik

Dalam tuturan, diawali oleh halaika selaku penutur memanggil anak-anak pemegang hak waris dari almarhum yang memiliki Alu Mama yang dinyatakan dalam satu larik, secara gramatikal larik I matra I merupakan unsur keterangan vokatif, sedangkan larik II merupakan keterangan waktu. Dalam peta kognitif 2 menunjukkan kata ana 'anak' dan nésan 'isi' yang memiliki jumlah gayutan dan jalinan hampir sama dengan ana 'anak'. Namun dilihat dari isi keseluruhan uturan tersebut ide inti ada pada larik III matra I,

\begin{tabular}{|c|c|c|}
\hline $\begin{array}{l}\text { Hé } \\
\text { néu ala }\end{array}$ & $\begin{array}{l}\text { ta'sana' } \\
k i\end{array}$ & in \\
\hline PREP & 1J-buka & $3 \mathrm{~T}$ \\
\hline
\end{tabular}

Larik ini subjeknya tidak dinyatakan. Berdasarkan bentuk verbanya ta'sana, yang 
disertai proklitikisasi pronomina persona I jamak sertaan menunjukkan subjeknya adalah hit 'kita' pronomina persona jamak sertaan. Namun, kata in merupakan pronomina yang merujuk kepada alu ama 'kantong/tas ayah' sebagai pembatas posesif terhadap nésan begitu juga alaki 'semua' sebagai pembatas peruntukkan, yang yang dimarkahi preposisi néu 'untuk'. Dengan demikian ide intinya berada pada pernyataan hit ta'sana nésan (alu ama) 'kita bongkar isi (alu ama)'. Jadi topik globalnya adalah nésan 'isi'.

Suatu hal yang menarik dalam tuturan tesebut bukannya ana yang membuka nésan alu ama melainkan dinyatakan dalam bentuk verbanya adalah kita. Yang dimaksud-kan dalam pronomina sertaan ini adalah halaika beserta semua anak-anak dari ayah kandung yang memiliki alu 'kantong, tas'. Hal ini menunjukkan betapa sakralnya acara tersebut sehingga dalam proses pembukaan alu mama harus dipimpin oleh pejabat agama suku, atau pemimpin spiritual, yang bisa berhubungan dengan roh leluhurnya.

Walaupun kata ana mendominasi hubungan antarunsur yang membangun teks tuturan ritual itu, namun jika ditelusuri secara cermat, ana 'anak' hanya menjadi objek penerima, bahkan dalam peta kognitif 2 menunjukkan kehadiran ana 'anak' merupakan unsur pembatas posesif terhadap ama. Pembatas posisif ini dapat diartikan sebagai kehadiran ama 'bapak' yang telah meninggal diwakilkan oleh benda-benda kepunyaannya.

Ritual ini harus dihadiri oleh seorang pemimpin Halaika oleh karena kepercayaan bahwa seorang ayah yang telah meninggal, rohnya kelak akan menjadi amuf 'leluhur' yang menjaga keturunannya sehingga bentuk lingual maus 'pusaka' adalah keterwakilan ikatan yang tidak putus tersebut. Jika diperhatikan dengan saksama, secara morfologis, bentuk lingual ana 'anak', menjadi ama 'bapak' dan akan menjadi amuf 'leluhur'. Variasi kata secara morfofonemik ini terkait dengan perubahan makna budaya dalam siklus kehiduapan.

Ketika seorang laki-laki masih kecil, disebut ana 'anak'. Anak tersebut menjadi besar dan memiliki seorang keluarga sehingga disebut ama 'bapak'. Hingga suatu saat dia meninggal dunia, dipercayai rohnya disebut amuf 'leluhur'. Tingkatan ini menggambarkan siklus hidup seorang pria pada masyarakat Boti. Jika digambarkan, maka akan seperti gambar di bawah ini.

\section{Gambar 1}

Morfofonemik dan Jalinan Makna dalam Siklus Kehidupan

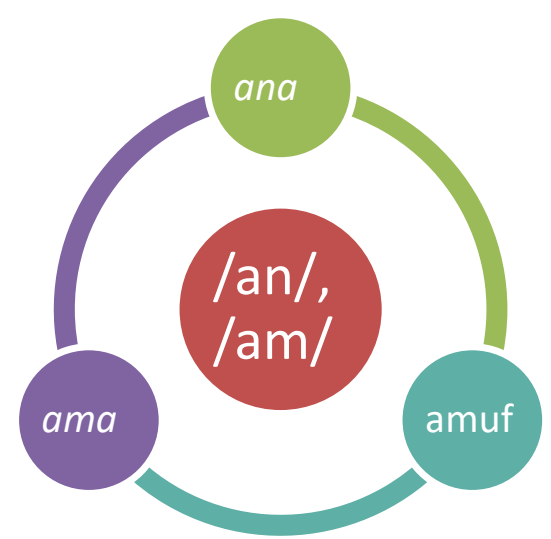

Berdasarkan gambar 1, akan muncul pertanyaan bagaimana kaitan amuf 'leluhur' dengan ana 'anak'. Pada penjelasan beberapa ritual kelahiran, seorang anak pada masyarakat Boti dinamai berdasarkan nama leluhurnya. Acara pemberian nama ini dipimpin oleh seorang pemimpin Halaika yang berbicara memanggil nama-nama leluhur dari anak laki-laki tersebut. Apabila sang anak berhenti menangis, maka nama tersebut diberikan kepadanya sebagai pelindung.

Citraan persepsi juga dapat ditelusuri dengan mengasosiasikan bentuk lingual ana 'anak' dengan nesan 'isi'. Jika diperhatikan arah anak panah jalinan yang membangun teks, terlihat bahwa ada dua titik yang menjadi pusatnya. Meskipun nésan menjadi topiknya karena sebagai benda mati, menjadikan medan maknanya objek tujuan, sedang pelakunya tindakannya adalah ana 
dan hit 'kita' (ana dan halaika).Ide-ide utama yang membangun teks tersebut dapat digambarkan dengan peta kognitif 3.

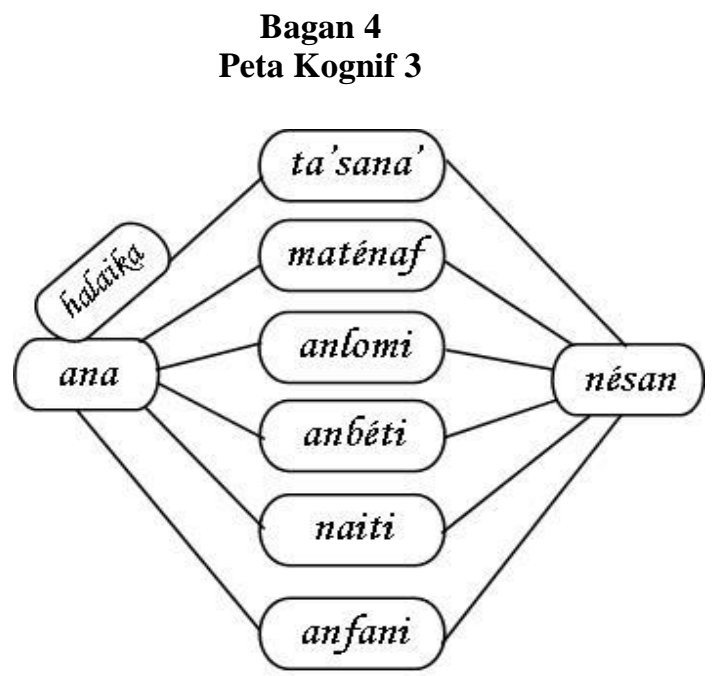

Peta Kognif 3.

Jalinan Ide Utama Tuturan Ritual Sef Alumama

Kalimat dasar yang membangun teks tuturan ritual Sèf Alu Mama terjemahannya sebagai berikut.

anak-anak dan halaika membongkar isi

(alu ama);

anak-anak memperhatikan isi (alu

ama);

anak-anak memperhatikan isi (alu

ama);

anak-anak mengingini isi (alu ama);

anak-anak memilih isi (alu ama);

anak-anak mengambil isi (alu ama);

anak-anak menjadikan isi (alu ama

sebagai pusaka, tanda peringatan)

Berdasarkan penjelasan di atas, alur tekstual terbentuk dari bentuk lingual ana 'anak' dan nesan 'isi'. Sebagaimana yang disampaikan dalam bagian pendahuluan kajian linguistik kebudayaan haruslah menggunakan data kebahasaan, teori bahasa, dan metode penelitian bahasa bukan kajian budaya. Penjelasan di atas, menjelaskan bentuk lingual dalam hubungan tekstual. Alur pembahasan dimulai dari membedah teks tuturan ritual Sef Alumama 'membuka
Alu Mama' dengan teori semiotik de Saussure. Kerangka teori yang dipakai menggunakan beberapa konsep dari kajian wacana seperti peta kognitif yang dikembangkan oleh Beaugrande. Hal ini penting untuk mencari asosisi tanda yang diwakili oleh bentuk lingual berdasarkan kelas kata.

Lebih lanjut, kajian linguistik kebudayaan seperti ini akan menghasilkan gambaran sintakmatik dan paradigmatik, topik global dan rasionalisasi sistem kognisi sosial. Linguistik kebudayaan menggunakan data kebahasaan yang di glosing kata perkata, identifikasi kelas kata, dan makna harifiahnya. Dengan cara demikian, kajian linguistik kebudyaaan haruslah memenuhi kaidah pengelolahan data penelitian bahasa.

Hubungan teks Analisis data telah mencapai tataran objektif, yaitu interpretasi hubungan tekstual dari bentuk lingual ke bentuk lingual. Pada tataran ini, fungsi kelas kata dalam rangkaian sintakmatik menjadi kunci dalam membedah teks. Langkahlangkah teoritis seperti ini yang terus dikembangkan oleh peneliti dalam mengembangkan linguistik kebudayaan dalam koridor ilmu linguistik.

\section{PENUTUP}

Kajian linguistik kebudayaan dalam tuturan ritual Sèf Alumama 'buka Alu Mama' pada masyarakat Boti dapat dilakukan dengan penggunaan teori semiotik. Teori ini menjelaskan bahwa leksikon memiliki serangkain sistem penandaan seperti fitur prosidik, morfosintaksis, hubungan teks dan intertekstual. Visualisasi jalinan kebermaknaan dapat digambarkan dalam peta kognitif. Penggambaran ini menunjukkan gayutan bentuk lingual dengan bentuk lingual lainnya. Sampai pada tahapan ini terlihat atribut kebahasaan yang kaya akan makna dan dikaji dalam frame linguistik bukan sebagai kajian budaya.

Pada tataran interpretasi, kajian linguistik kebudayaan dalam tuturan ritual Sèf Alumama 'buka Alu Mama' 
menunjukkan kekayaan unsur lingual seperti penggunaan pronomina sebagai unsur morfosintaksis yang erat kaitannya dengan sastra lisan dalam ritual yang dimaksud. Berdasarkan pembahasan di atas, keterpaduan unsur-unsur pembentuk makna berkaitan erat dengan penggunaan pronomina dan kelas kata lainnya. Karateristik ini menjadi kekhasan bahasa $u a b$ meto, terutama dalam ragam bahasa sastra lisan. Dalam paradigma liguistik kebudayaan pronomina juga berfungsi sebagai pembangun citraan harmonisasi bunyi dan pemaknaan tinggi sebagai bagian dari bahasa ritual.

Lebih lanjut, morfofonemik ana 'anak', ama 'bapak', amuf 'leluhur' merupakan sebuah sistem penandaan. Penggunaan morfem an dan am dapat diintrepretasi sebagai penanda siklus kehidupan manusia lahir, hidup, dan mati. Penanda ana 'anak' mewakili kelahiran, ama 'bapak' perwujudan kehidupan dan amuf 'leluhur' sebagai penanda makna sesudah kematian. Keteraturan referensial ini, menujukkan linguistik kebudayaan memiliki teori-teori yang khas, salah satunya semiotik yang dapat digunakan untuk membedah teks dengan kekhasan linguistiknya.

Peneliti menyarankan penelitian lanjutan dengan menggunakan berbagai perangkat teknologi baik dalam pengelolahan korpus yang spesifik, analisa frekuensi dan amplitudo, dan analisa berbasis korpus data. Peneliti juga menyarankan suatu kajian pustaka mengenai semiotik terlebih khusus semiotik kognitif dalam linguistik kebudayaan.

\section{DAFTAR PUSTAKA}

Alexandra, A., \& Lu, R. (2004). Clitics as Morphology Ana Alexandra Ribeiro Luís Department of Language and Linguistics.

Bragg, D., Koller, O., Bellard, M., Berke, L., Boudreault, P., Braffort, A., Caselli, N., Huenerfauth, M., Kacorri, H., Verhoef,
T., Vogler, C., \& Morris, M. R. (2019). Sign language recognition, generation, and translation: An interdisciplinary perspective. ASSETS 2019 - 21st International ACM SIGACCESS Conference on Computers and Accessibility, 16-31. https://doi.org/10.1145/3308561.33537 74

Casas, R., \& Campoy, J. (1995). A Sociolinguistic Approach to the study of Idioms: Some anthropolinguistic sketches. Cuadernos de Filología Inglesa, 4, 43-61. http://revistas.um.es/cfi/article/view/52 911/0

Delanty, G. (2006). Handbook of contemporary European social theory. In Handbook of Contemporary European Social Theory. https://doi.org/10.4324/9780203086476

Durst-Andersen, P. (2008). Linguistics as Semiotics. Saussure and Bühler Revisited . International Journal of Semiotics, 2, 1-29.

Durst-Andersen, P., Smith, V., \& Thomsen, O. N. (2013). Towards a CognitiveSemiotic Typology of Motion Verbs. The Construal of Spatial Meaning, 118-143.

https://doi.org/10.1093/acprof:oso/9780 199641635.003.0008

Ellis, N. C. (2019). Essentials of a Theory of Language Cognition. Modern Language Journal, 103, 39-60. https://doi.org/10.1111/modl.12532

Gehman, J., Glaser, V. L., Eisenhardt, K. M., Gioia, D., Langley, A., \& Corley, K. G. (2018). Finding Theory-Method Fit: A Comparison of Three Qualitative Approaches to Theory Building. Journal of Management Inquiry, 27(3), 284-300.

https://doi.org/10.1177/1056492617706 029

Heath, R., Mckinely, J., \& Baffoe-Djan, J. B. (2020). Data collection research methods in applied linguisitics. 
Research methods in linguistics. 9(1), $158-160$.

Iswanto. (2018). Supernatural Signification

System Amuf on Death Ritual Speech

Nen Fen Nahat Neu Nitu in Boti Society. 4(2), 46-57.

Iswanto. (2020). Tradisi Lisan Natoni dalam

Tuturan Ritual Sium Ana Pada Masyarakat Boti di Nusa Tenggara Timur. Walasuji: Jurnal Sejarah Dan Budaya, 11(1), 87-96. https://doi.org/10.36869/wjsb.v11i1.70

Jun, W. (2019). On the Indexical Nature of Language. Language and Semiotic Studies, 5(4), 46-57. https://doi.org/10.1111/j.17496632.1976.tb25470.x

Kemple, B. (2019). Semiotics, Communication and Cognition Volume 20. de Gruyter.

Liang, S. (2015). Language Attitudes and Identities in Multilingual China. Springer.

Manugeren, M., Sibarani, R., Nasution, I., \& Takari, M. (2017). Local Wisdom in Hindu Tamil Ethnic Wedding Tradition in Medan. International Journal of Research in Humanities \& Soc. Sciences, 5(2012), 38-48.

Nesi, A., Rahardi, R. K., \& Pranowo. (2010). Nilai-Nilai Kearifan Lokal Kajian Ekolinguistik. Jurnal Pendidikan Dan Kebudayaan Missio, 11(3), 71-90.

Nosowicz, J. F., \& Szerszunowicz, J. (2015). Preliminary Remarks on the Interdisciplinary Nature of Anthropolinguistics. Linguistics and Literature Studies, 3(6), 289-295. https://doi.org/10.13189/1ls.2015.03060 6

Santosa, P. (2016). Kearifan Budaya dan Fungsi Kemasyarakatan dalam Sastra Lisan Kafoa (Local Wisdom and Communal Function in The Oral Literature of Kafoa). METASASTRA: Jurnal Penelitian Sastra, 5(1), 67. https://doi.org/10.26610/metasastra.201 2.v5i1.67-82

Sataloff, R. T., Johns, M. M., \& Kost, K. M. (206 C.E.). Language and Ethicity. Cambridge University.

Sibarani, R. (2018). The local wisdom on Aren (Arenga pinnata) palm tree in Toba Batak tradition of North Sumatera at Lake Toba Area. Journal of Physics: Conference Series, 1116(5). https://doi.org/10.1088/17426596/1116/5/052060

Snell, J., Shaw, S., \& Copland, F. (2015). Linguistic Ethnography: Interdisciplinary Explorations. In Palgrave advances in language and linguistics. Palgrave Macmillan.

Sundler, A. J., Lindberg, E., Nilsson, C., \& Palmér, L. (2019). Qualitative thematic analysis based on descriptive phenomenology. Nursing Open, 6(3), 733-739.

https://doi.org/10.1002/nop2.275

Tomlinson, M. (2014). Bringing Kierkegaard into anthropology: Repetition, absurdity, and curses in Fiji. American Ethnologist, 41(1), 163175.

https://doi.org/10.1111/amet.12066

Udoye, I. E. (2019). Globalization and Awka Personal Names: An Anthropolinguistic Study. KIU Journal of Humanities, 4(1), 49-55. https://doi.org/10.31730/osf.io/pqaev

Umanailo, M. C. B. (2019). Overview Phenomenological Research. 1-6. https://doi.org/10.31226/osf.io/ntzfm

Zlatev, J. (2009). The Semiotic Hierarchy: Life, consciousness, signs and language. Cognitive Semiotics, 2009(4), 169-200. https://doi.org/10.3726/81608_169

Zlatev, J. (2012). Cognitive Semiotics: An emerging field for the transdisciplinary study of meaning. Public Journal of Semiotics, 4(1), 2-24. https://doi.org/10.37693/pjos.2012.4.83 7 
Totobuang, Vol. 9, No. 1, Juni 2021: 1-13 